\title{
Posterior fossa anomalies: related anomalies and the methods of pregnancy termination
}

\author{
Emine Aydın', Mert Turgal², Sema Can'1, Özgür Özyüncü' \\ ${ }^{1}$ Department of Obstetrics and Gynecology, Faculty of Medicine, Hacettepe University, Ankara, Turkey \\ ${ }^{2}$ Gynecology and Obstetrics Clinic, Dr. Sami Ulus Training and Research Hospital, Ankara, Turkey
}

\begin{abstract}
Objective: Posterior fossa anomalies are the group of heterogeneous malformations which are relatively common but still unclear. In this study, we aimed to evaluate the presence of concurrent anomaly in fetuses diagnosed with posterior fossa anomaly, and the methods of pregnancy termination.

Methods: A total of 56 cases matching the criteria and established with the posterior fossa anomaly during prenatal period were determined by ultrasonography or fetal magnetic resonance imaging (MRI) where possible. Medical histories, presence of concurrent anomalies, confirmation of diagnoses postnatally, results of fetal MRI if any, results of cases which were terminated and had autopsy, and genetic evaluations were recorded. The anomalies (posterior fossa anomaly and additional concurrent anomalies) found in the autopsy in cases, which were terminated, were compared with the anomalies detected during prenatal diagnosis.

Results: Of 56 cases with posterior fossa anomaly detected by prenatal ultrasonography, 29 cases had Dandy-Walker malformation (51.7\%), 19 cases had mega cisterna magna (33.9\%), and 8 cases had hypogenesis/hypoplasia (14.2\%). Termination option was preferred by 11 patients. Mean diagnosis week of patients who had termination was $22.0 \pm 4.36$ weeks of gestation, mean diagnosis week of patients who delivered was $31.0 \pm 4.73$ weeks. Twenty-one (37.5\%) patients refused karyotype analysis. The results of karyotype analysis of 31 $(55.3 \%)$ patients were normal. $46 \mathrm{XY}$,ins $(12 ; 2)$ was found in one fetus, $\mathrm{L} 1$ cell adhesion molecule (L1CAM) gene mutation was found in one fetus, and trisomy 18 was found in one fetus.

Conclusion: In cases with posterior fossa anomaly, karyotype analysis and the presence of additional concurrent anomaly are the elements that should be included in the patient follow-up. Fetal MRI, beginning to draw attention today, is a method useful in posterior fossa evaluation.
\end{abstract}

Keywords: Anomalie, Dandy-Walker syndrom, fossa, posterior.

\section{Özet: Posterior fossa anomalileri: iliş̧kili anomaliler} ve gebeliklerin sonlanma şekilleri

Amaç: Posterior fossa anomalileri göreceli olarak sık ama halen net olarak anlaşılamamış heterojen bir malformasyonlar grubudur. Bu çalışmada posterior fossa anomalisi tanısı almış fetüslerde eşlik eden anomali varlığı ve gebeliklerin sonlanma şekillerinin değerlendirilmesi amaçlanmıştır.

Yöntem: Ultrasonografi veya mümkün olduğunda fetal manyetik rezonans görüntüleme (MRG) yapılarak prenatal dönemde posterior fossa anomalisi tanısı almış, kriterlere uyan 56 olgu belirlendi. Gebeliklerin medikal öyküleri, eşlik eden anomalilerin varlığ postnatal olarak tanıların doğrulanıp doğrulanmadığı, fetal MRG varsa sonuçları, terminasyon uygulanan olgulardan otopsisi olanların sonuçları, genetik değerlendirmeler kaydedildi. Terminasyon uygulanan olguların otopsi sonucunda tespit edilen anomaliler (posterior fossa anomalisi ve eşlik eden ek anomaliler), prenatal tanı anında tespit edilen anomaliler karşılaştırıldı.

Bulgular: Prenatal ultrasonografi ile tespit edilen toplam 56 posterior fossa anomalisi olgusundan, 29'u Dandy-Walker malformasyonu (\% 51.7), 19'u mega sisterna magna (\%33.9), 8'i vermis hipogenezisi/hipoplazisi (\% 14.2) idi. On bir hasta terminasyon seçeneğini kullanmıştı. Terminasyon seçeneğini kullanan hastaların ortalama tanı haftası $22.0 \pm 4.36$ gestasyonel hafta iken, doğumla sonuçlanan olguların ortalama tanı haftası $31.0 \pm 4.73$ idi. Yirmi bir (\%37.5) hasta karyotip analizini kabul etmemişti. Otuz bir (\% 55.3) hastanın karyotip analizi normal saptanmıştı. Bir fetüste 46XY, ins(12;2), bir fetüste L1 cell adhesion molecule (L1CAM) gen mutasyonu, bir fetüste trizomi 18 saptanmıştı.

Sonuç: Posterior fossa anomalisi olgularında karyotip analizi ve eşlik eden ek anomali varlığı hastanın takibinde bulunması gereken unsurlardır. Fetal MRG günümüzde dikkat çekmeye başlayan, posterior fossa değerlendirmesinde faydalı olan bir yöntemdir.

Anahtar sözcükler: Anomali, Dandy-Walker sendromu, fossa, posterior.
Correspondence: Emine Aydın, MD. Hacettepe Üniversitesi Tıp Fakültesi, Kadın Hast. ve Doğum Anabilim Dalı, Ankara, Turkey. e-mail: eminebaskurtaydin@gmail.com

Received: April 12, 2016; Accepted: June 16, 2016

Please cite this article as: Aydın E, Turgal M, Can S, Özyüncü Ö. Posterior fossa anomalies: related anomalies and the methods of pregnancy termination. Perinatal Journal 2016;24(2):89-95.

(C2016 Perinatal Medicine Foundation
Available online at: www.perinataljournal.com/20160242006 doi:10.2399/prn.16.0242006 QR (Quick Response) Code:

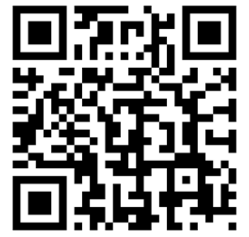




\section{Introduction}

Posterior fossa anomalies (PFA) are the group of heterogeneous malformations which are relatively common but still unclear. Dandy-Walker malformation (DWM), vermian hypogenesis/hypoplasia ( $\mathrm{VH}$ ) and mega cisterna magna (MSM) are seen in 1/5000 live birth. ${ }^{[1]}$ Routine posterior fossa evaluation including cerebellum, vermis and cisterna magna has a significant importance as there are more than one hundred syndromes covering this area. ${ }^{[2]}$ This area can be evaluated with ultrasonography or fetal magnetic resonance imaging (MRI) where possible. Fetal MRI is a technology capable of imaging soft tissues in more details and it helps to distinguish DWM, VH and MSM which have different prognosis compared to each other. ${ }^{[3,4]}$ Also, the findings such as fourth ventricle imaging, the presence of vermis and the presence of primary fissure can be evaluated more clearly by transvaginal ultrasonographic evaluation today. ${ }^{[5,6]}$ In posterior fossa evaluation, in which the experience of evaluator is significant as well as the technology used in imaging, (a) tentorium, (b) axis, size and morphology of vermis, and (c) the presence of space-occupying lesions or cyst (Blake's pouch cyst etc.) should be evaluate. ${ }^{[7]}$

While intracranial and extracranial anomaly risk increases in fetuses with posterior fossa anomaly, the most common anomalies are congenital cardiac anomalies (32\%), extremity anomalies (28\%), and renal and facial anomalies. ${ }^{[8]}$ In these infants, delays in neurological development are common and this rate was reported between 20 and $80 \%$ in many studies. ${ }^{[9-11]}$ While the prognosis is so variable, it causes trouble to physicians to inform the families of fetuses established prenatal

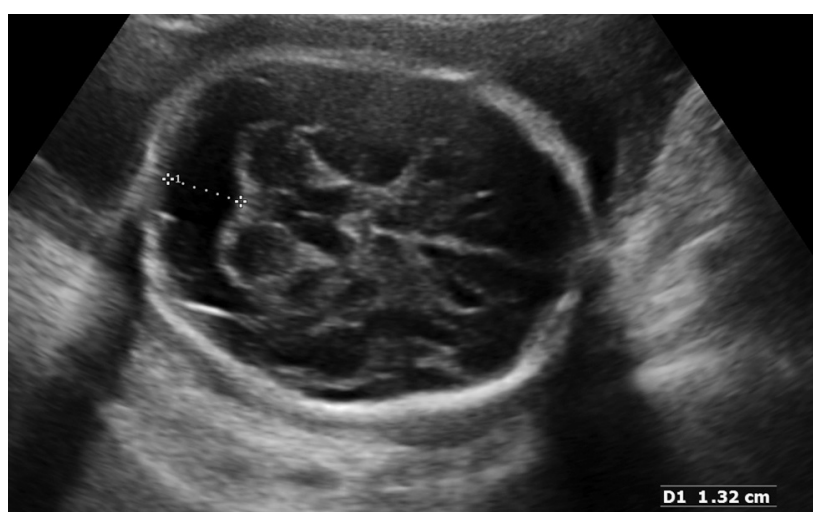

Fig. 1. A case with mega cisterna magna. diagnosis about the prognosis. The aim of this study is to determine the incidence rate of intracranial and extracranial anomalies in fetuses with PFA diagnosis and to evaluate the methods of termination in pregnancies diagnosed.

\section{Methods}

The study was carried out at Perinatology Department, Faculty of Medicine, Hacettepe University. The database was screened between 2004 and 2014. The cases established with PFA diagnosis during prenatal period were reached. Fifty-six cases matching the criteria were determined. When determining these cases, axial, coronal and sagittal cross-sections of 2D ultrasonography were used transabdominally. Transvaginal imaging was required only in 3 patients due to imaging quality.

As diagnosis criteria, the measurements and definitions standardized by Robinson et al. were used. ${ }^{[12]}$ MSM was considered as cisterna magna being higher than $10 \mathrm{~mm}$ (Fig. 1). Presence of small vermis together with normal foliation was evaluated as VH. DWM diagnostic criteria were determined as (a) vermian agenesia/hypogenesis, (b) cystic dilatation of 4th ventricle, and (c) increase of tentorium together with the extension of posterior fossa (Fig. 2). ${ }^{[13]}$ Ventriculomegaly (cases where lateral ventricle measurement is $10 \mathrm{~mm}$ and above at the level of choroid plexus glomus in axial plane and in the plane where ventricle's anterior horns, cavum septum pellucidum and choroid plexus can be seen) was associated with cerebrospinal fluid flow change and it was not considered as additional anomaly. ${ }^{[14]}$ Patient data were obtained from medical records

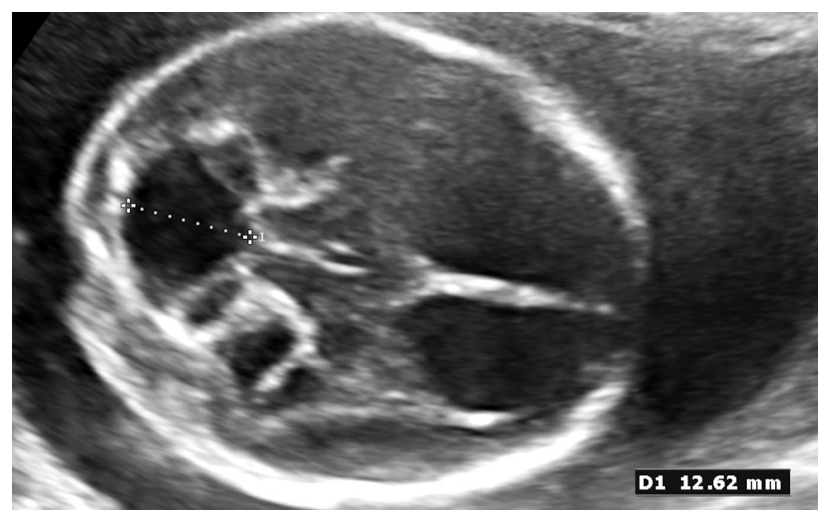

Fig. 2. A case with Dandy-Walker malformation. 
and by contacting to the patients via their registered phones (delivery, stillbirth, intrauterine fetal miss, termination). Medical histories, presence of concurrent anomalies, confirmation of diagnoses postnatally, results of fetal MRI if any, results of cases which were terminated and had autopsy, and genetic evaluations were recorded. The anomalies (PFA and additional concurrent anomalies) found in the autopsy in cases, which were terminated, were compared with the anomalies detected during prenatal diagnosis. For this study, approval no GO 16/161 was obtained from the Non-Invasive Procedures Ethics Committee of Hacettepe University. Definitive statistical analysis was done by SPSS 17.0 (Statistical Package for Windows, version 17.0; SPSS Inc., Chicago, IL, USA).

\section{Results}

Of 56 PFA cases detected by prenatal ultrasonography, $29(51.7 \%)$ cases had DWM, 19 (33.9\%) cases had MSM, and 8 (14.2\%) cases had VH (Table 1). All cases were referred to us from other centers. Mean age of the patients was $27.72 \pm 5.45$, mean gravida was $2.12 \pm 1.37$ and mean parity was $1.0 \pm 0.9$. Termination option was preferred by 11 patients. Mean diagnosis week of patients who had termination was $22.0 \pm 4.36$ weeks of gestation, mean diagnosis week of patients who delivered was $31.0 \pm 4.73$ weeks. Twenty-one (37.5\%) patients refused karyotype analysis. The results of karyotype analysis of $31(55.3 \%)$ patients were normal. $46 \mathrm{XY}$,ins $(12 ; 2)$ was found in one fetus, L1 cell adhesion molecule (L1CAM) gene mutation was found in one fetus, trisomy 18 was found in one fetus, and one fetus was thalassemia carrier.

Only the thalassemia carrier among the fetuses found to have karyotype anomaly was isolated, and others had additional anomaly. Hydrocephalia was found in the case having L1CAM gene mutation, nasal bone hypoplasia and right ventricle with double outflow were

Table 1. The distribution of cerebellar malformation diagnosis groups.

\begin{tabular}{lc} 
Diagnosis group & $\begin{array}{c}\text { Incidence (\%) } \\
\mathbf{N}=56\end{array}$ \\
\hline Dandy-Walker malformation (DWM) & $29(51.7 \%)$ \\
Mega cisterna magna (MSM) & $19(33.9 \%)$ \\
Vermis hypoplasia (VH) & $8(14.2 \%)$ \\
Total & $56(100 \%)$ \\
\hline
\end{tabular}

found in the case having 46XY, ins(12;2), and bilateral clubfoot, hypoplastic left heart, VSD and single umbilical artery was found in the case having trisomy 18 . Also, the other cases with normal karyotype had additional cranial and extracranial anomalies (Tables 2-4). Although dilatation in lateral ventricles was found in 23 (41\%) patients (cases where lateral ventricle measurement is $10 \mathrm{~mm}$ and above at the level of choroid plexus glomus in axial plane and in the plane where ventricle's anterior horns, cavum septum pellucidum and choroid plexus can be seen), this was not considered as an additional anomaly due to the reason stated above.

Six of the terminated fetuses were performed autopsy and the families of other fetuses refused an autopsy. DWM was found in five fetuses which were performed autopsy. No pathology was found in the pathological examination of cases which preferred termination and of the placentas in pregnancies which were delivered without preferring gestational termination. Fetal MR was applied in two cases since their ultrasonographic evaluation was unclear, and DWM was confirmed in both cases.

\section{Discussion}

As emphasized in the literature, first and main criterion of the DWM is the extension of posterior fossa associated with the upward localization of cerebellar tentorium. ${ }^{[15]}$ This location change is essentially based on the underlying pathology. As the normal position of tentorium corresponds to the symmetry of the insertion of occiput nuchal muscles, it is determined according to nuchal muscles. Even though these muscles are distinguished well with hypointense appearances in T2weighed MRI, they cannot be used as reference point since they cannot be distinguished from soft tissues in the ultrasonography. While fetal MRI is not an easily accessible imaging method due to technical reasons in our center, fetal MRI was applied to two cases since clear imaging could not be obtained in the diagnosis. Increase in tentorium occurring due to the extension of posterior fossa becomes significant in the diagnosis of these cases and the necessity of defining nuchal muscles is eliminated. Upward and too wide localization of tentorium causes the necessity of MRI and determining nuchal muscles to clarify the diagnosis. In this way, differential diagnosis of false positive cases, of which vermis develops normally, can be contributed. ${ }^{[14]}$ 
Table 2. Distribution of cases with DWM diagnosis.

\begin{tabular}{|c|c|c|c|c|c|}
\hline $\begin{array}{c}\text { Case } \\
\text { no }\end{array}$ & $\begin{array}{c}\text { Diagnosis week } \\
\text { (Gestational week) }\end{array}$ & Additional anomaly & $\begin{array}{l}\text { Karyotype } \\
\text { analysis }\end{array}$ & Autopsy result & $\begin{array}{l}\text { Gestational } \\
\text { outcome }\end{array}$ \\
\hline 1 & 24 & VSD, great artery transposition & Normal & DWM, VSD, great artery transposition & Medical termination \\
\hline 2 & 22 & $\mathrm{~N} / \mathrm{a}$ & $\mathrm{N} / \mathrm{a}$ & $\mathrm{N} / \mathrm{a}$ & Medical termination \\
\hline 3 & 19 & Corpus callosum agenesis & N/a & $\mathrm{N} / \mathrm{a}$ & Medical termination \\
\hline 4 & 26 & Microcephaly, single umbilical artery & N/a & $\mathrm{N} / \mathrm{a}$ & Labor at term \\
\hline 5 & 33 & $\mathrm{~N} / \mathrm{a}$ & $\mathrm{N} / \mathrm{a}$ & $\mathrm{N} / \mathrm{a}$ & Labor at term \\
\hline 6 & 18 & $\mathrm{~N} / \mathrm{a}$ & $\mathrm{N} / \mathrm{a}$ & $\mathrm{N} / \mathrm{a}$ & Medical termination \\
\hline 7 & N & $\begin{array}{c}\text { Macrocephaly, micrognathia, retrognathia, } \\
\text { low ear, flattened nasal root, } \\
\text { six fingers in all extremities, } \\
\text { renomegaly, bladder hypoplasia, } \\
\text { pancreatic cyst }\end{array}$ & a, & $\begin{array}{l}\text { DWM, macrocephaly, micrognathia, } \\
\text { retrognathia, low ear, flattened } \\
\text { nasal root, six fingers in } \\
\text { all extremities, renomegaly, } \\
\text { bladder hypoplasia, pancreatic cyst }\end{array}$ & Medical termination \\
\hline 8 & 31 & $\mathrm{~N} / \mathrm{a}$ & $\mathrm{N} / \mathrm{a}$ & $\mathrm{N} / \mathrm{a}$ & Labor at term \\
\hline 9 & 32 & $\mathrm{~N} / \mathrm{a}$ & $\mathrm{N} / \mathrm{a}$ & $\mathrm{N} / \mathrm{a}$ & Labor at term \\
\hline 10 & 21 & N/a & $\mathrm{N} / \mathrm{a}$ & $\mathrm{N} / \mathrm{a}$ & No follow-up \\
\hline 11 & 20 & $\mathrm{~N} / \mathrm{a}$ & N/a & $\mathrm{N} / \mathrm{a}$ & Medical termination \\
\hline 12 & 26 & $\mathrm{~N} / \mathrm{a}$ & $\mathrm{N} / \mathrm{a}$ & $\mathrm{N} / \mathrm{a}$ & No follow-up \\
\hline 13 & 31 & $\begin{array}{l}\text { Bilateral clubfoot, hypoplastic left } \\
\text { heart, VSD, single umbilical artery }\end{array}$ & Trisomy 18 & $\begin{array}{l}\text { Bilateral clubfoot, hypoplastic left } \\
\text { heart, VSD, single umbilical artery }\end{array}$ & Labor at term \\
\hline 14 & 34 & $\mathrm{~N} / \mathrm{a}$ & $\mathrm{N} / \mathrm{a}$ & $\mathrm{N} / \mathrm{a}$ & No follow-up \\
\hline 15 & 17 & N/a & N/a & DWM, dilatation at 4 th ventricle & Medical termination \\
\hline 16 & 19 & $\mathrm{~N} / \mathrm{a}$ & N/a & $\mathrm{N} / \mathrm{a}$ & No follow-up \\
\hline 17 & 30 & $\mathrm{~N} / \mathrm{a}$ & N/a & $\mathrm{N} / \mathrm{a}$ & Medical termination \\
\hline 18 & 24 & $\begin{array}{l}\text { Corpus callosum agenesis, } \\
\text { lung segmentation anomaly }\end{array}$ & $\begin{array}{l}\text { L1CAM gene } \\
\text { mutation }\end{array}$ & $\begin{array}{l}\text { DWM, corpus callosum agenesis, } \\
\text { lung segmentation anomaly }\end{array}$ & Medical termination \\
\hline 19 & 27 & $\mathrm{~N} / \mathrm{a}$ & $\mathrm{N} / \mathrm{a}$ & $\mathrm{N} / \mathrm{a}$ & No follow-up \\
\hline 20 & $\mathrm{~N} / \mathrm{a}$ & $\mathrm{N} / \mathrm{a}$ & $\mathrm{N} / \mathrm{a}$ & Labor at term & \\
\hline 21 & 21. & $\begin{array}{l}\text { Nasal bone hypoplasia, right } \\
\text { ventricle with double outflow }\end{array}$ & $46 X Y$ ins $(12 ; 2)$ & $\begin{array}{l}\text { Nasal bone hypoplasia, right } \\
\text { ventricle with double outflow }\end{array}$ & Medical termination \\
\hline 22 & 35 & $\mathrm{~N} / \mathrm{a}$ & $\mathrm{N} / \mathrm{a}$ & $\mathrm{N} / \mathrm{a}$ & Labor at term \\
\hline 23 & 35 & $\mathrm{~N} / \mathrm{a}$ & $\mathrm{N} / \mathrm{a}$ & $\mathrm{N} / \mathrm{a}$ & Labor at term \\
\hline 24 & 19 & $\mathrm{~N} / \mathrm{a}$ & $\mathrm{N} / \mathrm{a}$ & $\mathrm{N} / \mathrm{a}$ & No follow-up \\
\hline 25 & 17 & $\mathrm{~N} / \mathrm{a}$ & $\mathrm{N} / \mathrm{a}$ & $\mathrm{N} / \mathrm{a}$ & No follow-up \\
\hline 26 & 13 & $\mathrm{~N} / \mathrm{a}$ & $\mathrm{N} / \mathrm{a}$ & $\mathrm{N} / \mathrm{a}$ & Intrauterine ex \\
\hline 27 & 20 & $\mathrm{~N} / \mathrm{a}$ & $\mathrm{N} / \mathrm{a}$ & $\mathrm{N} / \mathrm{a}$ & No follow-up \\
\hline 28 & 33 & $\mathrm{~N} / \mathrm{a}$ & $\mathrm{N} / \mathrm{a}$ & $\mathrm{N} / \mathrm{a}$ & Labor at term \\
\hline 29 & 18 & N/a & $\mathrm{N} / \mathrm{a}$ & $\mathrm{N} / \mathrm{a}$ & No follow-up \\
\hline
\end{tabular}

DWM: Dandy-Walker malformation, N/a: not available, VSD: ventricular septal defect

In addition, in some studies which used 3D imaging methods were used ultrasonographically, the angles between brainstem-vermis and brainstem-tentorium were evaluated in such cases and it was shown that they can be helpful in the diagnosis. ${ }^{[16,17]}$

Although superior localization of cerebellar tentorium is a finding which can be detected at the end of first trimester and early second trimester, it is not supported to establish PFA diagnosis (agenesis, dysgenesis, hypoplasia) including vermis before 18 weeks of gestation as cerebellar vermis development still continues. ${ }^{[18]}$ In our series, mean week of diagnosis was 22 weeks of gestation. Although vermis anatomy is not understood clearly before 18 weeks of gestation, since this malformation exists as of the third month of preg- 
Table 3. Distribution of cases with mega cisterna magna.

\begin{tabular}{|c|c|c|c|c|c|}
\hline $\begin{array}{c}\text { Case } \\
\text { no }\end{array}$ & $\begin{array}{l}\text { Diagnosis week } \\
\text { (Gestational week) }\end{array}$ & Additional anomaly & $\begin{array}{l}\text { Karyotype } \\
\text { analysis }\end{array}$ & Autopsy result & $\begin{array}{l}\text { Gestational } \\
\text { outcome }\end{array}$ \\
\hline 1 & 26 & ASD, small cardiothoracic diameter & $\mathrm{N} / \mathrm{a}$ & N/a & No follow-up \\
\hline 2 & 32 & N/a & N/a & $\mathrm{N} / \mathrm{a}$ & No follow-up \\
\hline 3 & 39 & VSD, cyst in umbilical cord & $\mathrm{N} / \mathrm{a}$ & $\mathrm{N} / \mathrm{a}$ & No follow-up \\
\hline 4 & 32 & N/a & N/a & N/a & No follow-up \\
\hline 5 & 22 & $\begin{array}{l}\text { Left renal ureteropelvic junction stricture } \\
\text { (renal pelvis AP diameter }=9.4 \mathrm{~mm})\end{array}$ & $\mathrm{N} / \mathrm{a}$ & $\mathrm{N} / \mathrm{a}$ & No follow-up \\
\hline 6 & 25 & $\mathrm{~N} / \mathrm{a}$ & N/a & N/a & No follow-up \\
\hline 7 & 21 & Diaphragmatic hernia & $\mathrm{N} / \mathrm{a}$ & N/a & No follow-up \\
\hline 8 & 25 & $\begin{array}{l}\text { Flexion contractor in both hands, ASD, VSD, } \\
\text { multicystic dysplasia in both kidneys }\end{array}$ & $\mathrm{N} / \mathrm{a}$ & $\mathrm{N} / \mathrm{a}$ & Intrauterine ex \\
\hline 9 & 23 & Corpus callosum agenesis & Normal & $\mathrm{N} / \mathrm{a}$ & Labor at term \\
\hline 10 & 20 & $\mathrm{~N} / \mathrm{a}$ & Normal & $\mathrm{N} / \mathrm{a}$ & Labor at term \\
\hline 11 & 36 & $\mathrm{~N} / \mathrm{a}$ & $\mathrm{N} / \mathrm{a}$ & $\mathrm{N} / \mathrm{a}$ & Labor at term \\
\hline 12 & 33 & $\mathrm{~N} / \mathrm{a}$ & Normal & $\mathrm{N} / \mathrm{a}$ & Labor at term \\
\hline 13 & 35 & $\mathrm{~N} / \mathrm{a}$ & $\mathrm{N} / \mathrm{a}$ & $\mathrm{N} / \mathrm{a}$ & Labor at term \\
\hline 14 & 33 & N/a & N/a & N/a & Labor at term \\
\hline 15 & 23 & $\mathrm{~N} / \mathrm{a}$ & $\mathrm{N} / \mathrm{a}$ & $\mathrm{N} / \mathrm{a}$ & Labor at term \\
\hline 16 & 27 & $\mathrm{~N} / \mathrm{a}$ & $\mathrm{N} / \mathrm{a}$ & $\mathrm{N} / \mathrm{a}$ & Labor at term \\
\hline 17 & 30 & N/a & $\mathrm{N} / \mathrm{a}$ & $\mathrm{N} / \mathrm{a}$ & Labor at term \\
\hline 18 & 34 & $\mathrm{~N} / \mathrm{a}$ & N/a & $\mathrm{N} / \mathrm{a}$ & Labor at term \\
\hline 19 & 32 & Corpus callosum agenesis & $\mathrm{N} / \mathrm{a}$ & $\mathrm{N} / \mathrm{a}$ & Labor at term \\
\hline
\end{tabular}

AP: anteroposterior, ASD: atrial septal defect, N/a: not available, VSD: ventricular septal defect

nancy, the diagnosis can be established before this week if increase of tentorium can be defined clearly. ${ }^{[14]}$

Blake's pouch cyst (BPC) or arachnoid cysts which may create mass effect in tentorium can cause false positivity. ${ }^{[19]}$ These cysts do not affect entire tentorium but only the area in the distal of tentorium. With this focal increase, these cystic masses should be considered rather than DWM. ${ }^{[14]}$ In our series, there was no fetus with BPC or arachnoid cyst. In the typical ultrasonographic imaging of these fetuses, a small and thin continuing membrane is seen in the caudal part of inferior vermis in the prenatal and postnatal MRI imaging, and fourth ventri-

Table 4. The distribution of cases with vermian hypogenesis/hypoplasia.

\begin{tabular}{|c|c|c|c|c|c|}
\hline $\begin{array}{l}\text { Case } \\
\text { no }\end{array}$ & $\begin{array}{l}\text { Diagnosis week } \\
\text { (Gestational week) }\end{array}$ & Additional anomaly & $\begin{array}{c}\text { Karyotype } \\
\text { analysis }\end{array}$ & Autopsy result & $\begin{array}{l}\text { Gestational } \\
\text { outcome }\end{array}$ \\
\hline 1 & 22 & N/a & N/a & N/a & No follow-up \\
\hline 2 & 28 & $\mathrm{~N} / \mathrm{a}$ & $\mathrm{N} / \mathrm{a}$ & $\mathrm{N} / \mathrm{a}$ & No follow-up \\
\hline 3 & 29 & Corpus callosum agenesis & N/a & N/a & No follow-up \\
\hline 4 & 25 & $\mathrm{~N} / \mathrm{a}$ & $\mathrm{N} / \mathrm{a}$ & $\mathrm{N} / \mathrm{a}$ & No follow-up \\
\hline 5 & 20 & $\mathrm{~N} / \mathrm{a}$ & N/a & N/a & Medical termination \\
\hline 6 & 20 & $\mathrm{~N} / \mathrm{a}$ & $\mathrm{N} / \mathrm{a}$ & N/a & Medical termination \\
\hline 7 & 37 & Cleft palate-lip, VSD & N/a & $\mathrm{N} / \mathrm{a}$ & Labor at term \\
\hline 8 & 35 & N/a & $\mathrm{N} / \mathrm{a}$ & N/a & Labor at term \\
\hline
\end{tabular}

N/a: not available, VSD: ventricular septal defect 
cle is dilated. This membrane is the remnant of the posteroinferior part of the membraneous piece of primitive fourth ventricle.$^{[20]} \mathrm{BPC}$ should be remembered with the dilatation of fourth ventricle instead of DWM. ${ }^{[20]}$

Apart from them, as also highlighted in the literature, complete agenesis of vermis is seen in few patients; superior part of vermis is normal in most of them, and only inferior part is seen as thin. ${ }^{[14]}$ The current theory explaining the relationship between cystic malformation and varying levels of vermian hypoplasia states that it is a developmental defect involving the membraneous part of rhombencephalon. ${ }^{[12]}$ While it is difficult to make a distinction between malformed and normal vermis in the early phases of development, it is also difficult to evaluate lobulation and fissuration when decreased volume is detected. Pathological specimens obtained also support that hypoplasia disappears partially together with dysplasia and this is revealed with developmental disorganization. ${ }^{[15]}$ In our series, we did prenatal evaluation on all DWM and $\mathrm{VH}$ cases by the examination for the presence of two fissures and three lobs.

The importance of the presence of concurrent cranial anomaly was highlighted in various series and the absence of cranial anomaly draws attention in cases who maintain their lives normally. ${ }^{[10]}$ In our series, there were cranial anomalies found in cases with normal karyotype.

While DWM can be seen together with normal karyotype, the most common concurrent chromosomal anomalies are associated with $3 \mathrm{rd}$, 9th, 13th and 18th chromosomes. $^{[21]}$ In some series, 6th chromosome anomaly is the most common anomaly. ${ }^{[14]}$ We also had fetuses found to have chromosomal anomaly in our series, and trisomy 18 was one of them. Without checking the presence of chromosomal anomaly, all fetuses should be screened in terms of cranial and extracranial anomalies (congenital cardiac anomalies, eye anomalies, developmental defects, and dysmorphosis). High-resolution screening methods are significant particularly in cases where cardiac anomaly accompanies DWM. ${ }^{[2]} \mathrm{In}$ our series, cases found to have trisomy 18 (hypoplastic left heart) and 46XY, ins(12;2) (right ventricle with double outflow) also had cardiac anomaly, and fetuses which were normal for chromosome also had cardiac anomaly (great artery transposition in one fetus and VSD in one fetus). In addition, facial deformities, cleft palate-lip and lower-upper extremity deformities were reported among the concurrent anomalies similar to our series. ${ }^{[14]}$

\section{Conclusion}

Consequently, in cases with PFA, karyotype analysis and the presence of additional concurrent anomaly are the elements that should be included in the patient follow-up. Fetal MRI, beginning to draw attention today, is an imaging method useful in identifying concurrent cranial anomalies by anatomic evaluation of vermis, lobulation and fissuration, and it cannot be applied in all centers yet due to the technical reasons.

Conflicts of Interest: No conflicts declared.

\section{References}

1. Parisi MA, Dobyns WB. Human malformations of the midbrain and hindbrain: review and proposed classification scheme. Mol Genet Metab 2003;80:36-53.

2. De Catte L, De Keersmaeker B, Claus F. Prenatal neurologic anomalies: sonographic diagnosis and treatment. Paediatr Drugs 2012;14:143-55.

3. Adamsbaum C, Moutard ML, André C, Merzoug V, Ferey S, Quéré MP, et al. MRI of the fetal posterior fossa. Pediatr Radiol 2005;35:124-40.

4. Limperopoulos C, du Plessis AJ. Disorders of cerebellar growth and development. Curr Opin Pediatr 2006;18:621-7.

5. Goldstein I, Makhoul IR, Tamir A, Rajamim BS, Nisman D. Ultrasonographic nomograms of the fetal fourth ventricle: additional tool for detecting abnormalities of the posterior fossa. J Ultrasound Med 2002;21:849-56.

6. Zalel Y, Seidman DS, Brand N, Lipitz S, Achiron R. The development of the fetal vermis: an in-utero sonographic evaluation. Ultrasound Obstet Gynecol 2002;19:136-9.

7. Garel C, Moutard ML. Main congenital cerebral anomalies: how prenatal imaging aids counseling. Fetal Diagn Ther 2014;35:229-39.

8. Ecker JL, Shipp TD, Bromley B, Benacerraf B. The sonographic diagnosis of Dandy-Walker and Dandy-Walker variant: associated findings and outcomes. Prenat Diagn 2000;20:328-32.

9. Bolduc ME, Limperopoulos C. Neurodevelopmental outcomes in children with cerebellar malformations: a systematic review. Dev Med Child Neurol 2009;51:256-67.

10. Klein O, Pierre-Kahn A, Boddaert N, Parisot D, Brunelle F. Dandy-Walker malformation: prenatal diagnosis and prognosis. Childs Nerv Syst 2003;19:484-9.

11. Gerszten PC, Albright AL. Relationship between cerebellar appearance and function in children with Dandy-Walker syndrome. Pediatr Neurosurg 1995;23:86-92.

12. Robinson AJ, Blaser S, Toi A, Chitayat D, Halliday W, Pantazi S, et al. The fetal cerebellar vermis: assessment for abnormal development by ultrasonography and magnetic resonance imaging. Ultrasound Q 2007;23:211-23.

13. Dandy WE. Internal hydrocephalus. An experimental, clinical and pathological study. Am J Dis Child 1914;8:406-82. 
14. Guibaud L, Larroque A, Ville D, Sanlaville D, Till M, Gaucherand P, et al. Prenatal diagnosis of 'isolated' DandyWalker malformation: imaging findings and prenatal counselling. Prenat Diagn 2012;32:185-93.

15. Guibaud L, des Portes V. Plea for an anatomical approach to abnormalities of the posterior fossa in prenatal diagnosis. Ultrasound Obstet Gynecol 2006;27:477-81.

16. Contro E, Volpe P, De Musso F, Muto B, Ghi T, De Robertis V, et al. Open fourth ventricle prior to 20 weeks' gestation: a benign finding? Ultrasound Obstet Gynecol 2014;43:154-8.

17. Ghi T, Contro E, De Musso F, Farina A, Conturso R, Bonasoni $\mathrm{P}$, et al. Normal morphometry of fetal posterior fossa at midtrimester: brainstem-tentorium angle and brainstem-vermis angle. Prenat Diagn 2012;32:440-3.
18. Bromley B, Nadel AS, Pauker S, Estroff JA, Benacerraf BR. Closure of the cerebellar vermis: evaluation with second trimester US. Radiology 1994;193:761-3.

19. Garel C. Posterior fossa malformations: main features and limits in prenatal diagnosis. Pediatr Radiol 2010;40:1038-45.

20. Robinson AJ, Goldstein R. The cisterna magna septa: vestigial remnants of Blake's pouch and a potential new marker for normal development of the rhombencephalon. J Ultrasound Med 2007;26:83-95.

21. Imataka G, Yamanouchi H, Arisaka O. Dandy-Walker syndrome and chromosomal abnormalities. Congenit Anom (Kyoto) 2007;47:113-8.

22. Lin RJ, Cherry AM, Chen KC, Lyons M, Hoyme HE, Hudgins L. Terminal deletion of $6 p$ results in a recognizable phenotype. Am J Med Genet A 2005;136:162-8. 